\title{
Heat Shock Protein 70 (HSP70) Induction: Chaperonotherapy for Neuroprotection after Brain Injury
}

\author{
Jong Youl Kim ${ }^{1}$, Sumit Barua ${ }^{1}$, Mei Ying Huang ${ }^{1,2}$, Joohyun Park ${ }^{1,2}$, Midori A. Yenari ${ }^{3, *}$ and \\ Jong Eun Lee ${ }^{1,2, * \mathbb{D}}$ \\ 1 Department of Anatomy, Yonsei University College of Medicine, Seoul 03722, Korea; \\ jongyoulkim@yuhs.ac (J.Y.K.); sumit@yuhs.ac (S.B.); mayhuang@yuhs.ac (M.Y.H.); jhpark922@yuhs.ac (J.P.) \\ 2 BK21 Plus Project for Medical Science and Brain Research Institute, Yonsei University College of Medicine, \\ 50-1 Yonsei-ro, Seodaemun-gu, Seoul 03722, Korea \\ 3 Department of Neurology, University of California, San Francisco \& the San Francisco Veterans Affairs \\ Medical Center, Neurology (127) VAMC 4150 Clement St., San Francisco, CA 94121, USA \\ * Correspondence: yenari@alum.mit.edu (M.A.Y.); jelee@yuhs.ac (J.E.L.); Tel.: +1-415-750-2011 (M.A.Y.); \\ +82-2-2228-1646 (ext. 1659) (J.E.L.); Fax: +1-415-750-2273 (M.A.Y.); +82-2-365-0700 (J.E.L.)
}

Received: 17 July 2020; Accepted: 26 August 2020; Published: 2 September 2020

\begin{abstract}
The $70 \mathrm{kDa}$ heat shock protein (HSP70) is a stress-inducible protein that has been shown to protect the brain from various nervous system injuries. It allows cells to withstand potentially lethal insults through its chaperone functions. Its chaperone properties can assist in protein folding and prevent protein aggregation following several of these insults. Although its neuroprotective properties have been largely attributed to its chaperone functions, HSP70 may interact directly with proteins involved in cell death and inflammatory pathways following injury. Through the use of mutant animal models, gene transfer, or heat stress, a number of studies have now reported positive outcomes of HSP70 induction. However, these approaches are not practical for clinical translation. Thus, pharmaceutical compounds that can induce HSP70, mostly by inhibiting HSP90, have been investigated as potential therapies to mitigate neurological disease and lead to neuroprotection. This review summarizes the neuroprotective mechanisms of HSP70 and discusses potential ways in which this endogenous therapeutic molecule could be practically induced by pharmacological means to ultimately improve neurological outcomes in acute neurological disease.
\end{abstract}

Keywords: heat shock protein 70; brain injury; chaperone neuroprotection; pharmacological induction

\section{Introduction}

After various insults to the brain, a coordinated stress response which seems to protect it from further injury occurs. Heat shock proteins (HSPs) are the most exhaustively studied stress proteins. They were originally noted when sublethal heat stress was applied to cells. Postmortem studies have also documented induction of HSPs in the human brain following different types of thermal stress, such as hyperthermia or fire-related fatalities [1]. When core body temperature exceeded $40{ }^{\circ} \mathrm{C}$, increased transcripts of HSPs were detected in postmortem brain specimens. The study of autopsied brain specimens of patients who had suffered from hyperthermia also led to the conclusion that HSP70 induction could be a brain biomarker of death [2]. HSPs are chaperones that typically act within the cytosolic space, engaged in assisting with protein folding, degradation, complex assembly, and translocation. They have demonstrated the ability to inhibit the accumulation of damaged proteins as well as to facilitate the construction of polypeptides of newly synthesized proteins. The diverse roles by which HSP70 and HSP90 regulate aggregated proteins appear to be involved in neuroprotection as 
demonstrated by models of brain injury. HSP70 induction also represents an endogenous protective mechanism that occurs in the penumbra of the hippocampus, but not of other core areas, in the ischemic stroke model [3,4]. More than two decades of research involving such models have shown that HSP70 has the ability to protect against multiple types of cell death, including apoptosis and necrosis. Specifically, HSP70 interferes with multiple cell death pathways [5,6]. HSP70 also modulates inflammatory pathways and, thus, appears to improve neurological outcomes through interrupting both cell death and immune responses [7]. It should be noted, however, that these studies possessed limited translational utility because they relied upon either genetic mutant models or gene transfer models, and upon heat stress to induce HSP70 overexpression. In the HSP70 research trajectory, multiple disciplines have studied geldanamycin (GA) and 17-allyamino-demethoxygeldamycin (17-AAG), which block HSP90 leading to the induction of HSP70 [8,9]. The possible clinical applications of HSP70-inducing pharmacological compounds in neuroprotective therapies for ischemic stroke and associated conditions warrant further research [8]. Here, we discuss the mechanisms of HSP70 neuroprotection in brain injury (ischemic stroke and traumatic brain injury (TBI)), along with pharmacological HSP70 inducers and their possible applications at the clinical level.

\section{Classification and Functional Role of Heat Shock Protein 70}

At the onset of brain injury (for instance, of ischemic stroke or TBI), the synthesis of most cellular proteins is downregulated. However, HSPs belong to a small class of proteins that are, instead, upregulated, and have been collectively referred to as stress proteins. HSPs are classified in accordance to their molecular mass. Constitutive HSPs, such as HSP90, HSP40, and HSP70, have housekeeping functions within the cell [10]. HSP70 and HSP90 are two highly conserved ATP-dependent HSPs that modulate unfolded proteins.

HSP90 is an ATP-dependent chaperone associated with protein homeostasis [11]. It is required for the homeostasis of a number of key cellular proteins and protein complexes. HSP90 client proteins belong to distinct functional classes, such as transcription factors (e.g., HIF1 $\alpha$, ATF3, and p53), steroid hormone receptors (e.g., estrogen receptor, glucocorticoid receptor, and progesterone receptor), and kinases (e.g., EGFR, B-raf, and SRC). HSP90 and cochaperones bind to client proteins in an ordered pathway that involves sequential ATP-dependent interactions of the client protein with HSP70 and HSP90 [12]. Cochaperones are fundamental in regulating the ATP enzymatic activity of HSP90 in the cytoplasm and in mediating interactions between HSP90 and substrate $[12,13]$. They regulate the function of HSP90 by either inhibiting or activating the ATPase of HSP90 and by recruiting specific client proteins in different ways $[14,15]$. HSP90 directs the folding and activation of a wide variety of substrate proteins, most of which are kinases and transcription factors involved in signal transduction and regulatory processes [16,17]. Furthermore, many diverse pathological conditions such as cancer, neurodegenerative diseases, and infectious diseases involve HSPs. Of note, HSP90 functions in tandem with many additional chaperones, including HSP70 and HSP40, and also with cochaperones, including those containing tetratricopeptide repeat (TPR), to refold many denatured proteins [18].

HSP70 exists in several forms, which are either constitutive or inducible. Heat stress is an HSP70 catalyst for brain cells; it produces a marked expression of induced HSP70 family chaperones [19]. The neuroprotective properties associated with HSP70 have been the most comprehensively studied. HSP70 family chaperones exist in a multitude of different forms, including cytosolic, HSP73 (also Heat shock cognate [HSC]70); inducible cytosolic, HSP72; mitochondrial, HSP75/mortalin; and ER, HSP78/BIP. Other variants of HSP70 include HSP72 and HSP70i. HSP70 reacts to hydrophobic peptide segments, and these reactions are ATP-dependent. In HSP70, a C-terminal substrate-binding domain works to identify unstructured polypeptide segments, while a N-terminal ATPase domain is involved in HSP70's protein folding functions. For the protein folding role, HSP70 fluctuates between ATP-bound open and closed states with low and high substrate affinity, respectively [20].

The chaperone functions of HSP70 and HSP90 work in a coordinated manner to improve denatured protein stability [21]. In contrast to the refolding function of these proteins, when HSP90 is blocked 
by pharmacological substances such as GA or 17-AAG, it rapidly degrades client proteins through the ubiquitin-proteasome pathway [22]. Moreover, HSP70 and its cochaperone HSP40 assist in the degradation of various proteins [21].

\section{Mechanism of Heat Shock Protein 70 Induction and Its Interactions with Cochaperones and Client Proteins}

HSP transcription is regulated by transcription factor-heat shock factors (HSFs), which are translocated into the nucleus where they interact with conserved heat shock elements (HSEs) to upregulate genes that code for the induced HSPs. HSEs are generally located in the upstream untranslated region of HSFs target genes. HSF activation is accomplished at the level of protein-protein interaction and posttranslational modification [23]. Conversely, some HSFs expressed through HSPA1A/B/L (HSP70), HSPA1A (HSP72), and HSPC1 (HSP90), directly interrupt HSFs through binding to its trimerization domain. In addition, a cytoplasmic histone deacetylase and a valosin-containing protein lead to the suppression of the HSF-HSP complex [24].

Ischemia and other conditions, which are associated with unfolded proteins, lead to the dissociation of HSFs from HSPs. Dissociated HSFs migrate to the nucleus of the stressed cell, where they become phosphorylated, often by a protein such as kinase $\mathrm{C}$. This process forms activated trimers that bind to the HSE, which is a highly conserved regulatory sequence located on the heat shock gene. After binding to HSE, HSFs then bind to the HSP70 gene's promoter region, which leads to more HSP70 generation [8]. HSP70 production is influenced by HSP90, because the latter binds to HSF1. HSF1 can be freed to bind to HSEs in instances where HSP90 dissociates from it, thus facilitating further HSP70 induction [25].

The ATPs, HSP40 and HSP90 induce HSP70 synthesis and act as the molecular chaperones of damaged cells by repairing their denatured proteins. This role is completed through refolding and trafficking of the denatured proteins in the damaged cells, ultimately resulting in a multiple iteration of protein refolding. HSP40 binds to HSP70 with high affinity and is responsible for the ATPase activity of HSP70 and for maintaining it in an ADP-bound state. HSP40, by itself, cannot stabilize HSP70's ADP state. Due to this, and because of newly minted HSP70-substrate complexes, early dissociation occurs [26]. Thus, there are additional cochaperones involved. HSP70 interacting protein (HIP) binds to the HSP70 ATPase domain, thus maintaining HSP70's ADP-bound state, and protects the chaperone-substrate complex from dissociating [26]. Another cofactor, HSP70/HSP90-organization protein (HOP), binds to the HSP70 C-terminus, allowing HOP to recruit HSP90 to the HSP70 substrate complex [27-29]. As HIP stabilizes the ADP/ATP exchange of HSP70, HOP's interaction with HSP70 and HSP90 releases HSP70 chaperone components (Figure 1A). HSP70 utilizes its cochaperones, CHIP (C-terminus of HSP70/HSC70 interacting protein) and Bcl-2-associated athanogene (Bag)-1, indirectly for its role in protein degeneration (Figure 1B). CHIP, an ubiquitin ligase, interacts with HSP70 by rounding unfolded proteins and then ubiquitinating them, thus facilitating the degradation of seized proteins $[30,31]$. Under stress conditions, HSP70 induction is improved by CHIP function. Moreover, CHIP regulates HSP70's development in the stress recovery process; it probably achieves protein homeostasis by regulating chaperone levels while in stress and recovery processes [32]. Bag-1, an HSP70 cochaperone, is also associated with the proteasomal degradation of abnormal proteins. Bag- 1 and CHIP's interaction and co-expression directly enhance the model chaperone substrate degradation [33]. They work together to update the chaperone systems from a protein folding role to a degradation function. HSP90 is interlinked with HSP70 regarding protein degradation. Both chaperones transitorily associate with shared cochaperones. HSP90 transfers client proteins to HSP70 via a transient interaction. CHIP, that is associated to HSP70, ubiquitinates and pushes client proteins to proteasome mechanisms (Figure 1B) [34-36]. Thus, HSP90 is an inhibitor to substrate ubiquitination and degradation. In contrast, HSP70 is a promoter of ubiquitination and degradation $[37,38]$. 


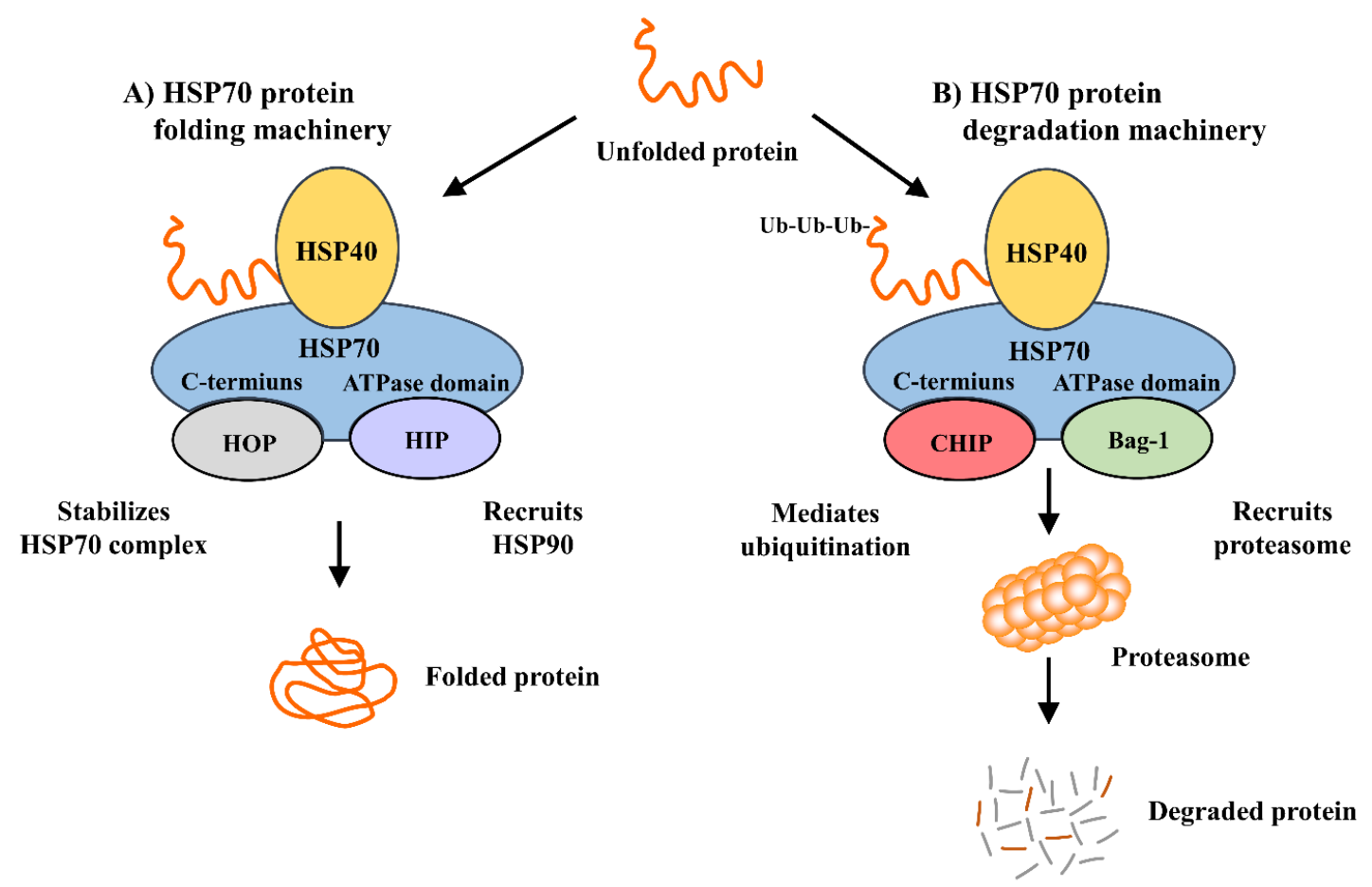

Figure 1. HSP70 chaperone machinery. HOP and CHIP compete for HSP70's C-terminus during protein folding and degradation, while HIP and Bag-1 compete for the ATPase domain. Depending on the site of HIP or Bag-1 binding, HSP70 may lead to protein folding (HIP/HOP pathway; (A) or to protein degradation through the proteasome (CHIP/Bag-1 pathway; $(\mathbf{B}) . \mathrm{Ub}=$ ubiquitin.

\section{Role of Heat Shock Protein 70 in Brain Injury}

Injury to the brain either from loss of blood flow or direct trauma to the brain evokes a complex multicellular pathophysiological state. Such injuries lead to different types of cellular damage, ranging from acute excitotoxic stress to instances of delayed programmed cell death. Inducible HSP70 levels are low while in homeostasis; however, injury drastically raises its expression. Therefore, HSP70 is demonstrated to be a marker of stress in cells. HSP70 induction was originally studied in a stroke model; within this model, HSP70 was initially observed in neurons of the brain regions that appeared relatively resistant to injury $[39,40]$. It was also detected in brain regions surrounding the infarct (penumbra) [41]. Later, HSP70 was observed in endothelial cells and glia, such as astrocytes and microglia [41]. In particular, HSP70 was detected in the brain regions surrounding the area of stroke (penumbra), but was absent in the areas most affected by the infarct (core) [42]. However, HSP70 mRNA was still detected within this core [41]. Thus, it was concluded that HSP70 was mainly detected in cells that survived the ischemic insult, while brain areas that failed to translate HSP70 remained vulnerable to ischemic injury. Similarly, in a model of global cerebral ischemia, which attempts to recreate ischemic brain injury due to cardiac arrest, HSP70 was mainly observed in the cornu amonis (CA) 3 and the dentate granules of the hippocampus that tend to survive the ischemic episode, whereas HSP70 was not induced in CA1 neurons [43]. Equally to that observed in stroke models, HSP70 mRNA was detected in all ischemic hippocampal regions, including CA1 neurons. However, CA1 neurons, which tend to be more vulnerable to ischemic insults compared to neurons of other hippocampal regions, failed to express the protein [44]. These observations generated debate as to whether HSP70 expression was an epiphenomenon of the injury or facilitated cell survival.

Experimentation demonstrating that HSP70 overexpression using viral vectors improved survival of neurons and astrocytes in stroke models finally provided direct evidence of a neuroprotective role of HSP70 [45,46]. Similarly, transgenic mice that overexpress HSP70 have smaller lesion sizes and better neurological outcomes, whereas a deficiency exacerbates lesions and poor outcomes $[47,48]$. 
Although less studied compared to brain ischemia, HSP70 was found to exhibit similar patterns in experimental models of TBI [7]. Many mechanisms leading to this protective effect have since been demonstrated in stroke and related models, ranging from prevention of protein aggregates to modulation of cell death pathways [20].

\section{The Neuroprotective Effect of Heat Shock Protein 70 via Cell Death Pathways}

HSP70 induction can lower protein aggregates and intracellular inclusions [49], but specific chaperone interactions seem to underlie other ways in which HSP70 may lead to neuroprotection. After brain injury, apoptosis occurs either via the intrinsic or mitochondrial pathway [50] or via the extrinsic or surface receptor-mediated pathway [51]. Recent research demonstrated that HSP70 impedes apoptosis via direct and indirect means (Figure 2).

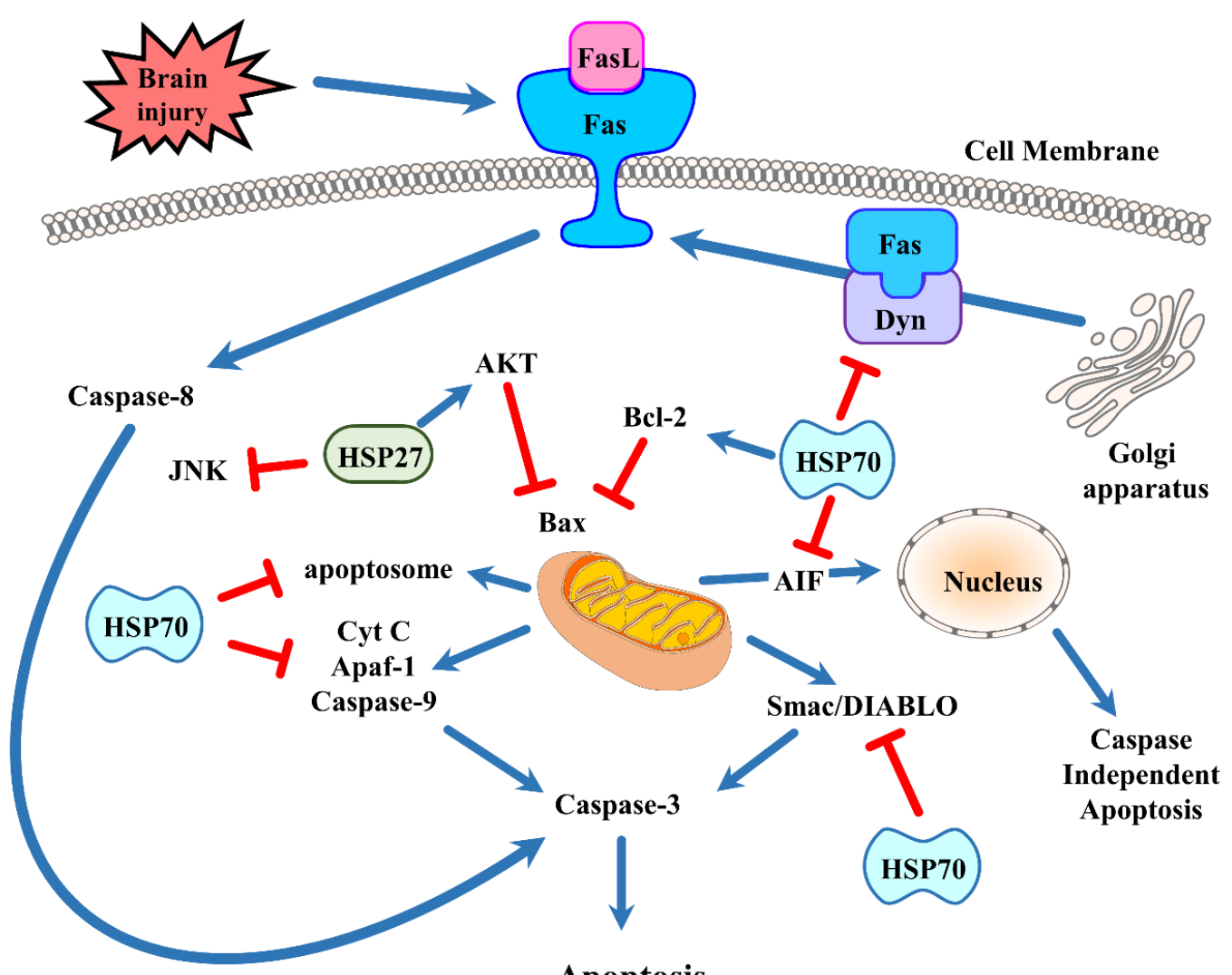

\section{Apoptosis}

Figure 2. Brain injury induces apoptotic cell death by distinct pathways. The intrinsic pathway is centered around signals emanating from the mitochondria, whereas the extrinsic or receptor-mediated pathway begins when death receptors bind to their ligands. The prototypical death receptor Fas is shown here. HSP70 and HSP27 have been shown to interfere with apoptosis as indicated in the figure. See text for more details. $(\mathrm{FasL}=$ Fas ligand; $\mathrm{AIF}=$ apoptosis inducing factor; $\mathrm{Akt}=$ protein kinase $\mathrm{B}$; Apaf-1 = apoptosis protease activating factor- 1 ; Cyt $\mathrm{C}=$ cytochrome c; JNK = c-Jun N-terminal kinase; Dyn = dynamin).

The intrinsic apoptotic pathway initiates with the release of various factors from the cell's mitochondria. In response to brain injury (and to the resultant oxidative stress), the mitochondria develop a permeability transition pore which leads to the discharge of cytochrome c to the cytosol, where a number of pro-apoptotic molecules ultimately causes the activation of effector caspases. Among these molecules are the Bcl-2 family members, some of which are pro-apoptotic. These molecules are primary regulators of the mitochondrial membrane. There are three subgroups classified by their structural homology. The first group includes the anti-apoptotic proteins Bcl-2, Bcl-XL, and Bcl-w. 
The second group includes the pro-apoptotic proteins Bax and Bak. The third group includes the BH3-only proteins Bad, Bid, Bim, Noxa, and PUMA. Bcl-2 family proteins conduct multiple functions during brain injury. BH3-only proteins, via interactions with Bcl-2 family members, assist with neuronal cell death after ischemic stroke [52]. Mitochondria-based apoptosis is related to the apoptosome. This occurs when procaspase-9 interacts with apoptosis protease activating factor-1 (Apaf-1) in the cytosol and leads to activation when cytochrome $\mathrm{c}$ is translocated to the cytosol from the mitochondria. Bcl-2, an antiapoptotic protein, interrupts cytochrome c release. Furthermore, caspase- 9 activation induces the activation of a multitude of effector caspases such as caspase-3. In neuronal stem cells, induction of HSP70 by recombination plasmid pEGFP-C2-HSP70 significantly blocks caspase- 3 and reduces neural cytotoxicity, including neuron loss and synapsis damnification, in cocultured cells [53]. After an inflammatory stimulus, oligodendrocyte precursor cells and mature oligodendrocytes of HSP70 deficient mice enter apoptosis caused by caspase-3 activation [54]. Caspase-independent pathways have been described to cause apoptosis via apoptosis inducing factor (AIF) [55]. AIF translocates into the nucleus from the mitochondria. Once in the nucleus, AIF can trigger apoptosis in the absence of caspases. Like cytochrome c, AIF release can also be prevented by Bcl-2 [56]. Second mitochondria-derived activator of caspases (Smac)/direct inhibitor-of-apoptosis protein (IAP) binding protein with low pi (Smac/DIABLO) is also a regulator of apoptosis. These are also discharged from the mitochondria and impede apoptosomal inhibition by IAPs. HSP70 seems to affect multiple aspects of the intrinsic apoptotic pathway. HSP70 interacts with components of the apoptotic machinery both upstream $[57,58]$ and downstream of mitochondrial events [59]. In experimental stroke models, HSP70 interfered with cytochrome c release $[43,60]$ and inhibited AIF translocation to the nucleus [61] while reducing ischemic brain injury. It lowers the recruitment of procaspase-9 into the apoptosome, as observed in HSP70 overexpressing transgenic mice, and sequesters AIF [62]. HSP70 also prevents the release of proapoptotic protein Smac/DIABLO from myocyte mitochondria [63]. Mitochondrial HSP70/HSP75/mortalin assistants act to maintain mitochondrial membrane potential, which could be beneficial to mitochondrial function and mitochondrial protein import [64]. Astrocytes with HSP induction showed reduced cell death following in vitro stroke models with preserved ATP [65]. The above outcomes are connected to lowered reactive oxygen species (ROS) creation, and maintained mitochondrial membrane potentials [66] and glutathione levels [67]. Overexpression of HSP70 has been demonstrated to elevate mitochondrial antioxidant enzyme activity in myocardial cells [68]. Bcl-2 is a critical component in hindering the onset of apoptosis due its ability to block the release of cytochrome $c$ and AIF, and viral vector-mediated HSP70 overexpression was linked to elevated Bcl-2 protein levels in hippocampal neurons [69]. HSP70 has also been shown to reduce heat-induced apoptosis by preventing the migration of the pro-apoptotic Bcl-2 family member Bax, and thus blocking the mitochondrial discharge of pro-apoptotic factors [58]. Previous studies of HSP27 and its anti-apoptotic activity have established that stress-induced Bax oligomerization and migration to the mitochondria can be suppressed indirectly by HSP27 [70]. HSP27 has also been shown to phosphorylate the survival kinase Akt/protein kinase B (PKB) [71] and to inactivate prodeath c-Jun N-terminal kinase (JNK) [72]. HSP70 also interferes with the activity of Apaf-1, a critical component for apoptosome formation and activation of caspase-9 [62], although others have failed to show such an interaction [57].

The extrinsic or cell surface-mediated pathway of apoptosis involves interactions with death receptors found on the plasma membrane. This pathway is also known as the "death receptor pathway". Death receptor ligation activates caspase- 8 and caspase-10. This has the potential to activate effector caspase-3 [73] . The TNF family of ligands, including FasL, TNF, CD40L, and TRAIL, promotes the activation of many death receptors. Many of these ligands are released extracellularly as part of the ischemic immune response [74]. One of the first death receptors identified was Fas, which activates when it binds to its ligand FasL. When FasL binds to Fas, the cytoplasmic adaptor protein Fas-associated death domain protein (FADD) is recruited to this complex. FADD possesses a "death effector domain" at the N-terminus that can bind to procaspase-8 [75]. This is known as the death-inducing signaling complex (DISC). 
The proteolytic cleavage, which causes transactivation of procaspase- 8 to caspase- 8 , is catalyzed by the DIAC [75]. Activated caspase- 8 ultimately leads to the activation of caspases-3 and -10 [76].

HSP70 has been demonstrated to engage with extrinsic death receptor signaling pathways. HSP70 is known to bind to cell surface receptors TRAILR1 and TRAILR2, and to death receptors 4 (DR4) and 5 (DR5), where they bind to a cytokine called TRAIL to induce TNF-related apoptosis. Therefore, the TRAIL-induced assembly and activity of the DISC becomes inhibited [77,78]. HSP70 can neutralize Bid activation and the following apoptosis once DISC formation has occurred and caspase- 8 has been activated [79]. HSP70 has been demonstrated to interact with the Fas pathway. Dynamin, a molecule typically associated with synaptic transmission, is also known to traffic Fas to the cell's surface from the Golgi apparatus [80]. Fas binds to FasL when it translocates to the cell surface, activating caspase- 8 and, therefore, leading to cell death. We recently showed that HSP70 inhibits Fas trafficking to the cell surface via its interaction with dynamin [48]. Thus, HSP70 also prevents the extrinsic or receptor-mediated apoptosis with specific chaperone interactions.

Several studies have shown that microRNAs (miRNAs), which interact with multiple target messenger RNAs (mRNAs), coordinate the regulation of target genes. Several miRNAs such as miRNA-1, miRNA-21, and miRNA-24 may contribute to an increased expression of several cytoprotective proteins, although no targets have been validated. Some studies showed that muscle-specific miRNA-1 levels can change in the condition of ischemic myocardium [81-83], and that two of miRNA-1's targets are HSP60 and HSP70 [84]. Recently, Ouyang et al. showed that miRNA-181a, which is expressed at high levels in the brain, regulates HSP70 family chaperones and the outcome of ischemic stroke [85]. Mutual expression of miRNA-181a and HSP78/BIP was found both in the core and the penumbra in an ischemic stroke model. miRNA-181a mimic reduces and its inhibitor/antagomir enhances HSP78/BIP expression [85]. miRNA-181a also targets Bcl2, which is an antiapoptotic protein [86] and has been shown to be upregulated by HSP70 overexpression [69]. miRNA-181 can also target HSP78/BIP and potentially target the 3' UTRs of HSP72 and HSP75/mortalin. Following ischemic stroke, miRNAs could conceivably target multiple chaperones and efficiently modulate cell death.

\section{Inflammation Regulation of Heat Shock Protein 70}

Inflammation of the central nervous system (CNS) is a feature of many acute neurological injuries, including brain trauma, stroke, and other cerebral hypoxic-ischemic injuries [87]. Brain injury elicits an inflammatory reaction beginning with the activation of endogenous microglia and with peripheral leukocyte influx into the cerebral parenchyma $[88,89]$. Upon inflammatory cell activation, cytotoxic agents such as some cytokines, which are increasingly viewed as key contributors to ischemic cell death [90], are discharged. Some studies indicate that nonimmunologic brain cells, such as astrocytes and even neurons, can elaborate these same inflammatory molecules. These inflammatory responses are thought to exacerbate brain damage, thus presenting a major opportunity for potential treatments. HSP70 has been demonstrated to possess a modulating role in regulating immune responses in cases of brain injury. HSP70 has been demonstrated to control inflammation both inside and outside the cell. In the intracellular setting, HSP70 appears to inhibit pro-immune responses; whereas in the extracellular setting, it seems to do the opposite and potentiate such responses.

HSP70 is capable of interacting with transcription factors, including those which trigger inflammations, such as the nuclear factor-kappaB (NF-kB, which consists of the heterodimers p65 and p50). One study in astrocytes showed that HSP70 was capable of reducing NF-kB activation [91]. HSP70 can also interact with immune molecules themselves, such as matrix metalloproteinases (MMPs) and ROS; it seems to limit inflammatory responses in such cases. Increased HSP70 within the cell has been shown to decrease the production of nitric oxide and inducible nitric oxide synthase (iNOS) in inflammatory cells. Heat stress is also associated with the reduced secretion of tumor necrosis factor-alpha (TNF- $\alpha$ ) as well as with diminished generation of ROS. HSP70 has been shown to inhibit the cellular responses to inflammatory cytokines including TNF- $\alpha$ and interleukin (IL)-1 [92,93], and 
increased HSP70 in macrophages prevents lipopolysaccharide (LPS)-induced increases in TNF, IL-1, IL-10, and IL-12 $[93,94]$. In a model of intracerebral hemorrhage, HSP70 also reduced TNF- $\alpha$ while attenuating blood brain barrier (BBB) disruption and brain edema, and enhanced neurological function as well [95].

Induction of HSP70 in phagocytes through heat shock decreased nicotinamide adenine dinucleotide phosphate hydrogen (NADPH) oxidase activity in neutrophils and increased superoxide dismutase, a superoxide scavenger [96]. Recently, we demonstrated that HSP70 induction by heat stress halts IkB, JNK, and p38 phosphorylation. HSP70 also seems to inhibit the binding to DNA of several transcription factors, including NF-kB, activator protein-1 (AP-1), and signal transducer and activator of transcription factor 1 (STAT-1), with subsequent inhibition of their pro-inflammatory transgenes [97]. Other studies have also demonstrated that prior-heat stress, due, in part, to HSP70 overexpression and prevention of nuclear NF-kB translocation, interferes with these inflammatory responses $[98,99]$. When ischemic stroke induces generation of cytokines, such as TNF- $\alpha$ that can activate NF-kB-dependent gene transcription through the NF-kB pathway, the inhibitor of kB (IkB) acts as another target of HSP70 and, when bound, can interrupt NF-kB activation by preventing phosphorylation of IkB (Figure 3) [91,92]. Some studies have also shown that HSP70 interacts with NF-kB and/or its regulatory proteins $[100,101]$, but the mechanisms may depend on the nature of the stimulus. In a cell death model induced by TNF- $\alpha$, HSP70 directly inhibited IkB kinase (IKK) activity [102], while in a stroke model, HSP70 seemed to interact with both NF-kB and IkB, ultimately leading to reduced IkB phosphorylation by IKK [100]. NF-kB inhibition by HSP70 further prevented transcription of immune genes and led to a neuroprotective effect.

NF-kB regulates many pro-inflammatory genes, including matrix metalloproteinase (MMP)-9. Our group showed that MMP-9 mRNA was reduced when HSP70 was overexpressed in astrocytes later exposed to ischemia-like injury [46]. Furthermore, HSP70 in astrocytes suppresses MMP-9 protein expression [46]. MMP-2, while not regulated by NF-kB, was also decreased in an HSP70 overexpression context, which suggests that HSP70 inhibits other transcription factors as well. In fact, studies in heat stressed alveolar macrophages [18] and primary astrocytes [97], showed that HSP70 interfered with STAT-1, which is known to regulate MMP-2 expression [103]. Additionally, HSP70 seems to inhibit the generation of activated MMPs, as evidenced by a reduction in cleaved forms of several MMPs. In a model of TBI, HSP70 overexpression inhibited, while HSP70 deficiency exacerbated, brain hemorrhage, and this was correlated with changes in MMP levels and activity [7]. Thus, there are several ways in which HSP70 inhibits the post injury immune response.

Extracellular HSP70 also has the capacity to modulate immune responses [104]. HSP70 has been shown to accomplish opposite roles depending on the type of insult and the immune response that follows. Extracellular HSP70 appears to potentiate adaptive immune responses, and has been widely studied. Complexes of HSP70 and peptides trigger CD8+T-cell responses [105]. Injecting mice with these HSP70-peptide complexes leads to similar responses, and suggests that HSP70 acts as an adjuvant [106]. In the extracellular environment, HSP70 can also potentiate antigen presentation, and reacts with macrophages and dendritic cells via CD40, CD91, and LOX-1 receptors [107]. Extracellular HSP70 has also been shown to elicit innate immune responses by interacting with Toll-like receptors (TLRs), causing subsequent NF-kB activation and target gene upregulation, including iNOS and pro-inflammatory cytokines [108]. HSP60 and HSP90 appear to interact with TLR-2 and -4 [109]; however, these results have been controversial, as some preparations of recombinant HSPs may have contained endotoxin, the classic ligand for TLR-4 [110]. 


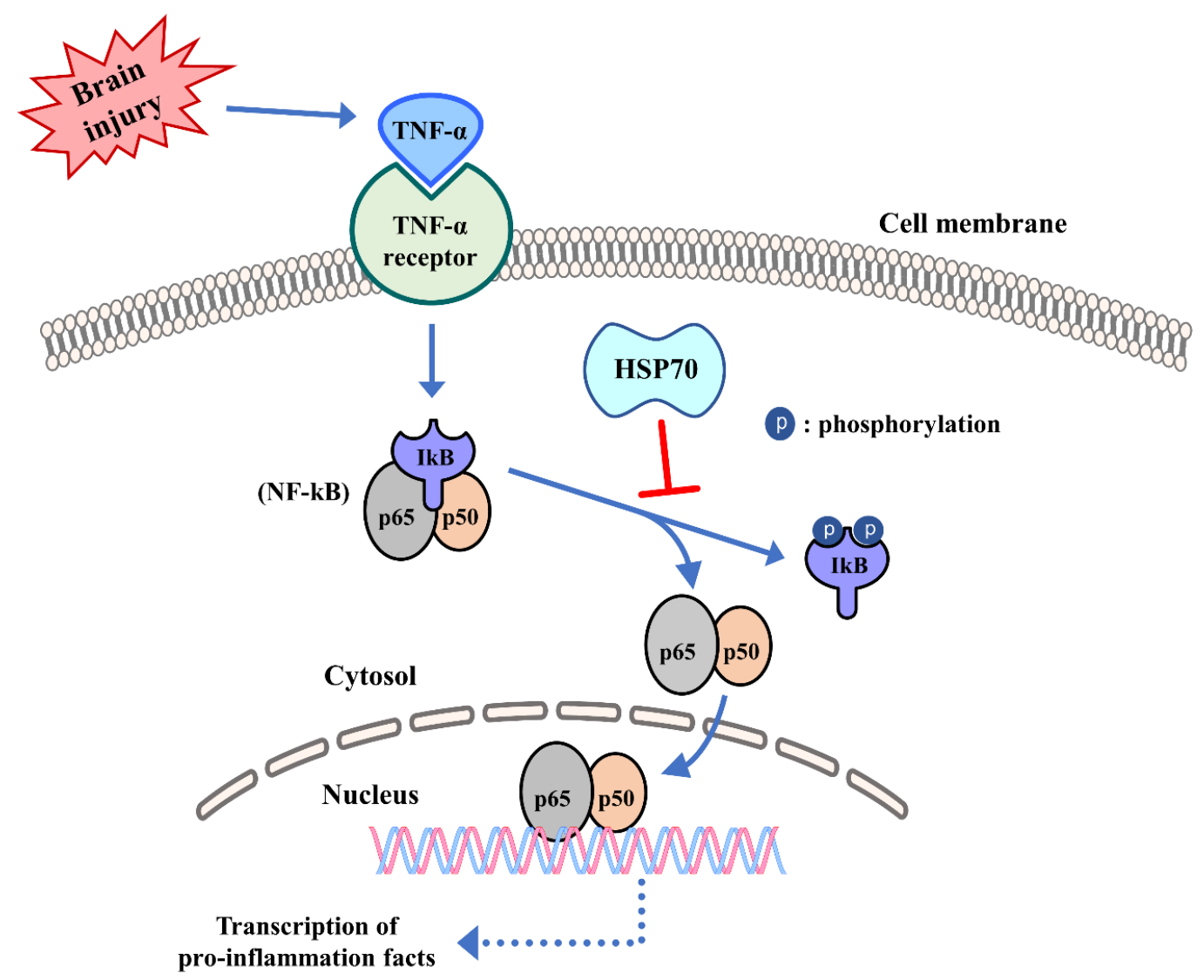

Figure 3. Influence of HSPs in innate immunity. Following ischemic stroke, HSPs have been shown to inhibit the activation of the transcription factor NF-kB and to prevent its nuclear translocation. Acute brain insults (brain injury) trigger activation of NF-kB by causing the phosphorylation and degradation of its inhibitor protein IkB, which normally keeps NF-kB (which consists of the heterodimers p65 and p50) tethered to the cytosol. Once NF-kB is able to translocate to the nucleus, it binds to promoter regions of several pro-inflammatory genes and leads to an inflammatory response.

\section{Heat Shock Protein 70 as a (Pharmacological) Therapeutic Target for Brain Injury}

Understanding the mechanisms by which HSPs function within the cell under conditions of stress and injury may reveal potential therapeutic targets. A few studies have attempted a direct delivery of HSP70 to the brain, while others have employed the cell's endogenous capacity to upregulate HSP70 through its coordinated actions with HSP90. After brain injury, treatments to increase HSP70 in the cell might be a worthwhile approach to treat neurological conditions associated with inflammation and cell death. A few pharmacological approaches to delivering HSP70 have been explored. In one study, exogenous HSP70 was conjugated to the HIV TAT protein in order to improve brain delivery following intravenous administration. HSP70-TAT reduced infarct volumes, improved neurological outcomes, and led to higher survival of neural progenitors in a stroke model [111]. Similar observations were found when recombinant HSP70 was administered in a rodent stroke model [112]. In this latter study, HSP70 was conjugated with Fv, which is a single chain fragment of the anti-DNA antibody mAb 3E10 that allows for penetration into the cell, and the $\mathrm{Fv}$ fragment was used as a delivery vehicle. Interestingly, systemic Fv-HSP70 treatment seemed to enter the ischemic side of the brain but not the contralateral nonischemic side, which suggests that it may bind to a still unknown target within the injured brain.

Since HSP90 sequesters HSF1 in the cytosol and prevents transcription of target HSPs, including HSP70, the administration of pharmacological inhibitors of HSP90 is another strategy to endogenously increase HSP70 expression. A few studies have now explored the efficacy of pharmacological induction 
of HSP70 via HSP90 inhibitors in brain injury models. This was recently reviewed by us, and we refer the reader to the review for more details on this topic [8]. Such inducers have shown salutary effects against both local and global experimental cerebral ischemia $[113,114]$. Due to the HSP70 abilities to reduce apoptosis and inflammation after ischemic stroke, there is an obvious interest in the HSP70 induction capacity of HSP90 inhibitor agents. One such HSP90-antagonist, GA, has been studied in stroke models with salutary results [113], but has failed at the clinical level due to poor solubility in water [115] and to unacceptable renal and hepatic toxicity [116,117]. The GA analogue 17-AAG is less toxic and has since advanced to phase 3 clinical trials for cancer therapy $[116,118]$. Consistent with the findings seen with GA, 17-AAG treatment improved outcomes in experimental TBI, with a reduction in brain hemorrhage [119]. 17-(2-dimethylaminoethyl) amino-17-demethoxygeldanamycin (17-DMAG), with better solubility, was developed, and was found to decrease microglial activation and to inhibit phosphorylation of IKB resulting in reduced nuclear translocation of NF-kB (p65) in a stroke model [120].

There are other HSP70-inducing groups, such as the purine-based compounds and the resorcinols. Purine-based compounds were designed to resemble ansamycins; hence, they use ADP to bind to HSP90's ATP binding site [121]. BIIB021 (also named CNF-2024) is also an HSP70-inducer and an HSP90-inhibitor. It is being studied in a phase 2 clinical trial using an oral form [118,122]. Another study in lymphoma cells demonstrated BIIB021 to be a potent anti-inflammatory compound that can suppress NF-kB [123]. What is still unclear is if these purine-based compounds accomplish the same roles in other types of cells, and whether they can penetrate the BBB. The resorcinol group includes radicicol based compounds, which bind to HSP90's ATP-binding pocket [124,125]. Despite their HSP90-inhibiting properties, drug development of the resorcinol groups is slow because they have been found to easily degrade in vivo [118]. Some variants such as NVP-AUY922 and AT-13387 were designed to avoid this limitation, and have also been studied as potential anti-inflammatory compounds for cancer treatment. Resorcinol has yet to be studied in brain injury or inflammation [118]. There is, however, some work published about another HSP70 inducer, geranylgeranylacetone (GGA), known for its antiulcer properties. In a stroke model, GGA led to not only a neuroprotective effect but also to a reduced post stroke inflammation via HSP70 upregulation and protein kinase C (PKC) activation [126,127]. Others found that the administration of GGA also led to a neuroprotective effect in a TBI model by inhibiting microglial activation and reducing apoptosis of neurons [128]. Thus, promising preclinical studies of HSP90 inhibitors together with clinical experience in cancer patients may stimulate appropriate trials in stroke and TBI patients.

Other pharmacological inducers of HSPs have been studied in models of neurodegeneration and cancer, but they have yet to be tested in brain injury models. Myricetin, a flavonoid, was shown to enhance intracellular levels of HSF-1 and HSP70, and to suppress abnormal protein aggregation and remove various toxic neurodegenerative disease-associated proteins [129]. Celastrol, a quinone methide family member isolated from the Thunder God Vine, has been shown to upregulate HSF-1, which, in turn, leads to HSP induction; this has been shown in human neuronal cells [130]. Celastrol has been shown to protect motor neurons from kainic acid induced excitotoxicity while upregulating HSPs [131]. Celastrol has also been shown to improve outcome in a stroke model, but this study did not explore whether this was related to HSP induction [132]. In a metastatic cancer model, a recent study showed that electrochemotherapy with betulinic acid or with cisplatin increased HSP27 and HSP70, and they proposed that electric field stress combined with drug administration led to the induction of HSPs [133]. Thus, promising observations in related nervous system disease models suggest that these approaches should be tested in acute brain injury models.

\section{Conclusions}

The role of the HSP family as potential neuroprotectants for the treatment of acute brain insults has been increasingly recognized, along with a more detailed elucidation of the mechanisms underlying this beneficial effect. Several studies have now reported a neuroprotective effect, particularly after 
HSP70 induction or administration through pharmacological manipulations. HSP70 also appears to be accountable for multiple protective mechanisms as a molecular chaperone. The multifaceted mechanisms of protection by HSPs suggest that these may be an effective therapeutic target. While some HSP90 inhibiting compounds have already been investigated in cancer clinical trials, there are no studies in patients with neurological conditions. With the development of several pharmacological HSP70 inducers and of methods to deliver the protein itself, it seems that we may be ready for clinical trials.

Author Contributions: J.E.L. and M.A.Y. provided concept, design and overall supervision of this study. J.Y.K. contributed in the writing and drawing. S.B., M.Y.H. and J.P. participated in the discussion and revision. All authors approved and agreed to be accountable for all aspects of the work. All authors have read and agreed to the published version of the manuscript.

Funding: This research was supported by grants from the National Institutes of Health (RO1 NS106441) and Department of Defense and the Veteran's Merit Award (I01 BX000589) to M.A.Y. Grants to M.A.Y. were administered by the Northern California Institute for Research and Education, and supported by resources of the Veterans Affairs Medical Center, San Francisco, California. Basic Science Research Program through the National Research. Foundation of Korea (NRF) funded by the Ministry of Education (NRF-2020R1I1A1A01064803) to J.Y.K., and the National Research Foundation of Korea (NRF) grant funded by the Korea Government (MSIP; NRF-2017R1A2B2005350) to J.E.L.

Conflicts of Interest: The authors declare that they have no competing interests.

\section{References}

1. Doberentz, E.; Genneper, L.; Wagner, R.; Madea, B. Expression times for hsp27 and hsp70 as an indicator of thermal stress during death due to fire. Int. J. Legal Med. 2017, 131, 1707-1718. [CrossRef]

2. Mash, D.C.; Duque, L.; Pablo, J.; Qin, Y.; Adi, N.; Hearn, W.L.; Hyma, B.A.; Karch, S.B.; Druid, H.; Wetli, C.V. Brain biomarkers for identifying excited delirium as a cause of sudden death. Forensic Sci. Int. 2009, 190, e13-e19. [CrossRef] [PubMed]

3. Weinstein, P.R.; Hong, S.; Sharp, F.R. Molecular identification of the ischemic penumbra. Stroke 2004, 35, 2666-2670. [CrossRef] [PubMed]

4. States, B.A.; Honkaniemi, J.; Weinstein, P.R.; Sharp, F.R. DNA fragmentation and hsp70 protein induction in hippocampus and cortex occurs in separate neurons following permanent middle cerebral artery occlusions. J. Cereb. Blood Flow Metab. 1996, 16, 1165-1175. [CrossRef] [PubMed]

5. Frebel, K.; Wiese, S. Signalling molecules essential for neuronal survival and differentiation. Biochem. Soc. Trans. 2006, 34, 1287-1290. [CrossRef] [PubMed]

6. De Maio, A. Extracellular hsp70: Export and function. Curr. Protein Pept. Sci. 2014, 15, 225-231. [CrossRef]

7. Kim, J.Y.; Kim, N.; Zheng, Z.; Lee, J.E.; Yenari, M.A. The 70 kda heat shock protein protects against experimental traumatic brain injury. Neurobiol. Dis. 2013, 58, 289-295. [CrossRef]

8. Kim, N.; Kim, J.Y.; Yenari, M.A. Anti-inflammatory properties and pharmacological induction of hsp70 after brain injury. Inflammopharmacology 2012, 20, 177-185. [CrossRef]

9. Kacimi, R.; Yenari, M.A. Pharmacologic heat shock protein 70 induction confers cytoprotection against inflammation in gliovascular cells. Glia 2015, 63, 1200-1212. [CrossRef]

10. Saibil, H. Chaperone machines for protein folding, unfolding and disaggregation. Nat. Rev. Mol. Cell Biol. 2013, 14, 630-642. [CrossRef]

11. Schopf, F.H.; Biebl, M.M.; Buchner, J. The hsp90 chaperone machinery. Nat. Rev. Mol. Cell Biol. 2017, 18, 345-360. [CrossRef] [PubMed]

12. Zuehlke, A.; Johnson, J.L. Hsp90 and co-chaperones twist the functions of diverse client proteins. Biopolymers 2010, 93, 211-217. [CrossRef]

13. Johnson, J.L.; Brown, C. Plasticity of the hsp90 chaperone machine in divergent eukaryotic organisms. Cell Stress Chaperones 2009, 14, 83-94. [CrossRef] [PubMed]

14. Taipale, M.; Jarosz, D.F.; Lindquist, S. Hsp90 at the hub of protein homeostasis: Emerging mechanistic insights. Nat. Rev. Mol. Cell Biol. 2010, 11, 515-528. [CrossRef]

15. Li, J.; Soroka, J.; Buchner, J. The hsp90 chaperone machinery: Conformational dynamics and regulation by co-chaperones. Biochim. Biophys. Acta 2012, 1823, 624-635. [CrossRef] 
16. Xu, Z.S.; Li, Z.Y.; Chen, Y.; Chen, M.; Li, L.C.; Ma, Y.Z. Heat shock protein 90 in plants: Molecular mechanisms and roles in stress responses. Int. J. Mol. Sci. 2012, 13, 15706-15723. [CrossRef] [PubMed]

17. Krukenberg, K.A.; Street, T.O.; Lavery, L.A.; Agard, D.A. Conformational dynamics of the molecular chaperone hsp90. Q. Rev. Biophys. 2011, 44, 229-255. [CrossRef] [PubMed]

18. Howard, M.; Roux, J.; Lee, H.; Miyazawa, B.; Lee, J.W.; Gartland, B.; Howard, A.J.; Matthay, M.A.; Carles, M.; Pittet, J.F. Activation of the stress protein response inhibits the stat1 signalling pathway and inos function in alveolar macrophages: Role of hsp90 and hsp70. Thorax 2010, 65, 346-353. [CrossRef] [PubMed]

19. Brown, I.R. Heat shock proteins and protection of the nervous system. Ann. N. Y. Acad. Sci. 2007, 1113, 147-158. [CrossRef]

20. Giffard, R.G.; Yenari, M.A. Many mechanisms for hsp70 protection from cerebral ischemia. J. Neurosurg. Anesthesiol. 2004, 16, 53-61. [CrossRef]

21. Sherman, M.Y.; Goldberg, A.L. Cellular defenses against unfolded proteins: A cell biologist thinks about neurodegenerative diseases. Neuronal 2001, 29, 15-32. [CrossRef]

22. Isaacs, J.S.; Xu, W.; Neckers, L. Heat shock protein 90 as a molecular target for cancer therapeutics. Cancer Cell 2003, 3, 213-217. [CrossRef]

23. Akerfelt, M.; Morimoto, R.I.; Sistonen, L. Heat shock factors: Integrators of cell stress, development and lifespan. Nat. Rev. Mol. Cell Biol. 2010, 11, 545-555. [CrossRef]

24. Pernet, L.; Faure, V.; Gilquin, B.; Dufour-Guerin, S.; Khochbin, S.; Vourc'h, C. Hdac6-ubiquitin interaction controls the duration of hsf1 activation after heat shock. Mol. Biol. Cell 2014, 25, 4187-4194. [CrossRef]

25. Zhao, H.; Michaelis, M.L.; Blagg, B.S. Hsp90 modulation for the treatment of alzheimer's disease. Adv. Pharmacol. 2012, 64, 1-25. [CrossRef]

26. Hohfeld, J.; Minami, Y.; Hartl, F.U. Hip, a novel cochaperone involved in the eukaryotic hsc70/hsp40 reaction cycle. Cell 1995, 83, 589-598. [CrossRef]

27. Frydman, J.; Hohfeld, J. Chaperones get in touch: The hip-hop connection. Trends Biochem. Sci. 1997, 22, 87-92. [CrossRef]

28. Chen, S.; Smith, D.F. Hop as an adaptor in the heat shock protein 70 (hsp70) and hsp90 chaperone machinery. J. Biol. Chem. 1998, 273, 35194-35200. [CrossRef]

29. Hernandez, M.P.; Sullivan, W.P.; Toft, D.O. The assembly and intermolecular properties of the hsp70-hop-hsp90 molecular chaperone complex. J. Biol. Chem. 2002, 277, 38294-38304. [CrossRef]

30. Connell, P.; Ballinger, C.A.; Jiang, J.; Wu, Y.; Thompson, L.J.; Hohfeld, J.; Patterson, C. The co-chaperone chip regulates protein triage decisions mediated by heat-shock proteins. Nat. Cell Biol. 2001, 3, 93-96. [CrossRef]

31. Murata, S.; Minami, Y.; Minami, M.; Chiba, T.; Tanaka, K. Chip is a chaperone-dependent e3 ligase that ubiquitylates unfolded protein. EMBO Rep. 2001, 2, 1133-1138. [CrossRef] [PubMed]

32. Qian, S.B.; McDonough, H.; Boellmann, F.; Cyr, D.M.; Patterson, C. Chip-mediated stress recovery by sequential ubiquitination of substrates and hsp70. Nature 2006, 440, 551-555. [CrossRef]

33. Demand, J.; Alberti, S.; Patterson, C.; Hohfeld, J. Cooperation of a ubiquitin domain protein and an e3 ubiquitin ligase during chaperone/proteasome coupling. Curr. Biol. 2001, 11, 1569-1577. [CrossRef]

34. Meacham, G.C.; Patterson, C.; Zhang, W.; Younger, J.M.; Cyr, D.M. The hsc70 co-chaperone chip targets immature cftr for proteasomal degradation. Nat. Cell Biol. 2001, 3, 100-105. [CrossRef] [PubMed]

35. Esser, C.; Scheffner, M.; Hohfeld, J. The chaperone-associated ubiquitin ligase chip is able to target p53 for proteasomal degradation. J. Biol. Chem. 2005, 280, 27443-27448. [CrossRef]

36. Luo, W.; Zhong, J.; Chang, R.; Hu, H.; Pandey, A.; Semenza, G.L. Hsp70 and chip selectively mediate ubiquitination and degradation of hypoxia-inducible factor (hif)-1alpha but not hif-2alpha. J. Biol. Chem. 2010, 285, 3651-3663. [CrossRef]

37. Peng, H.M.; Morishima, Y.; Clapp, K.M.; Lau, M.; Pratt, W.B.; Osawa, Y. Dynamic cycling with hsp90 stabilizes neuronal nitric oxide synthase through calmodulin-dependent inhibition of ubiquitination. Biochemistry 2009, 48, 8483-8490. [CrossRef]

38. Peng, H.M.; Morishima, Y.; Pratt, W.B.; Osawa, Y. Modulation of heme/substrate binding cleft of neuronal nitric-oxide synthase (nnos) regulates binding of hsp90 and hsp70 proteins and nnos ubiquitination. J. Biol. Chem. 2012, 287, 1556-1565. [CrossRef]

39. Nowak, T.S., Jr.; Bond, U.; Schlesinger, M.J. Heat shock rna levels in brain and other tissues after hyperthermia and transient ischemia. J. Neurochem. 1990, 54, 451-458. [CrossRef] 
40. Abe, K.; Tanzi, R.E.; Kogure, K. Induction of hsp70 mrna after transient ischemia in gerbil brain. Neurosci. Lett. 1991, 125, 166-168. [CrossRef]

41. Sharp, F.R.; Lu, A.; Tang, Y.; Millhorn, D.E. Multiple molecular penumbras after focal cerebral ischemia. J. Cereb. Blood Flow. Metab. 2000, 20, 1011-1032. [CrossRef] [PubMed]

42. Beretta, S.; Cuccione, E.; Versace, A.; Carone, D.; Riva, M.; Padovano, G.; Dell'Era, V.; Cai, R.; Monza, L.; Presotto, L.; et al. Cerebral collateral flow defines topography and evolution of molecular penumbra in experimental ischemic stroke. Neurobiol. Dis. 2015, 74, 305-313. [CrossRef] [PubMed]

43. Tsuchiya, D.; Hong, S.; Matsumori, Y.; Kayama, T.; Swanson, R.A.; Dillman, W.H.; Liu, J.; Panter, S.S.; Weinstein, P.R. Overexpression of rat heat shock protein 70 reduces neuronal injury after transient focal ischemia, transient global ischemia, or kainic acid-induced seizures. Neurosurgery 2003, 53, 1179-1187. [CrossRef] [PubMed]

44. DeGracia, D.J.; Jamison, J.T.; Szymanski, J.J.; Lewis, M.K. Translation arrest and ribonomics in post-ischemic brain: Layers and layers of players. J. Neurochem. 2008, 106, 2288-2301. [CrossRef] [PubMed]

45. Batulan, Z.; Taylor, D.M.; Aarons, R.J.; Minotti, S.; Doroudchi, M.M.; Nalbantoglu, J.; Durham, H.D. Induction of multiple heat shock proteins and neuroprotection in a primary culture model of familial amyotrophic lateral sclerosis. Neurobiol. Dis. 2006, 24, 213-225. [CrossRef]

46. Lee, J.E.; Kim, Y.J.; Kim, J.Y.; Lee, W.T.; Yenari, M.A.; Giffard, R.G. The 70 kda heat shock protein suppresses matrix metalloproteinases in astrocytes. Neuroreport 2004, 15, 499-502. [CrossRef]

47. Lee, S.H.; Kim, M.; Yoon, B.W.; Kim, Y.J.; Ma, S.J.; Roh, J.K.; Lee, J.S.; Seo, J.S. Targeted hsp70.1 disruption increases infarction volume after focal cerebral ischemia in mice. Stroke 2001, 32, 2905-2912. [CrossRef]

48. Kim, J.Y.; Kim, N.; Zheng, Z.; Lee, J.E.; Yenari, M.A. 70-kda heat shock protein downregulates dynamin in experimental stroke: A new therapeutic target? Stroke 2016, 47, 2103-2111. [CrossRef]

49. Hartl, F.U.; Hayer-Hartl, M. Molecular chaperones in the cytosol: From nascent chain to folded protein. Science 2002, 295, 1852-1858. [CrossRef]

50. Green, D.R.; Reed, J.C. Mitochondria and apoptosis. Science 1998, 281, 1309-1312. [CrossRef]

51. Ashkenazi, A.; Dixit, V.M. Death receptors: Signaling and modulation. Science 1998, 281, $1305-1308$. [CrossRef] [PubMed]

52. Okuno, S.; Saito, A.; Hayashi, T.; Chan, P.H. The c-jun n-terminal protein kinase signaling pathway mediates bax activation and subsequent neuronal apoptosis through interaction with bim after transient focal cerebral ischemia. J. Neurosci. 2004, 24, 7879-7887. [CrossRef] [PubMed]

53. Lu, D.; Xu, A.; Mai, H.; Zhao, J.; Zhang, C.; Qi, R.; Wang, H.; Lu, D.; Zhu, L. The synergistic effects of heat shock protein 70 and ginsenoside rg1 against tert-butyl hydroperoxide damage model in vitro. Oxid. Med. Cell Longev. 2015, 2015, 437127. [CrossRef] [PubMed]

54. Mansilla, M.J.; Costa, C.; Eixarch, H.; Tepavcevic, V.; Castillo, M.; Martin, R.; Lubetzki, C.; Aigrot, M.S.; Montalban, X.; Espejo, C. Hsp70 regulates immune response in experimental autoimmune encephalomyelitis. PLoS ONE 2014, 9, e105737. [CrossRef] [PubMed]

55. Susin, S.A.; Lorenzo, H.K.; Zamzami, N.; Marzo, I.; Snow, B.E.; Brothers, G.M.; Mangion, J.; Jacotot, E.; Costantini, P.; Loeffler, M.; et al. Molecular characterization of mitochondrial apoptosis-inducing factor. Nature 1999, 397, 441-446. [CrossRef] [PubMed]

56. Zhao, H.; Yenari, M.A.; Cheng, D.; Barreto-Chang, O.L.; Sapolsky, R.M.; Steinberg, G.K. Bcl-2 transfection via herpes simplex virus blocks apoptosis-inducing factor translocation after focal ischemia in the rat. J. Cereb. Blood Flow Metab. 2004, 24, 681-692. [CrossRef]

57. Steel, R.; Doherty, J.P.; Buzzard, K.; Clemons, N.; Hawkins, C.J.; Anderson, R.L. Hsp72 inhibits apoptosis upstream of the mitochondria and not through interactions with apaf-1. J. Biol. Chem. 2004, 279, 51490-51499. [CrossRef]

58. Stankiewicz, A.R.; Lachapelle, G.; Foo, C.P.; Radicioni, S.M.; Mosser, D.D. Hsp70 inhibits heat-induced apoptosis upstream of mitochondria by preventing bax translocation. J. Biol. Chem. 2005, 280, 38729-38739. [CrossRef]

59. Ravagnan, L.; Gurbuxani, S.; Susin, S.A.; Maisse, C.; Daugas, E.; Zamzami, N.; Mak, T.; Jaattela, M.; Penninger, J.M.; Garrido, C.; et al. Heat-shock protein 70 antagonizes apoptosis-inducing factor. Nat. Cell Biol. 2001, 3, 839-843. [CrossRef]

60. Lee, S.H.; Kwon, H.M.; Kim, Y.J.; Lee, K.M.; Kim, M.; Yoon, B.W. Effects of hsp70.1 gene knockout on the mitochondrial apoptotic pathway after focal cerebral ischemia. Stroke 2004, 35, 2195-2199. [CrossRef] 
61. Matsumori, Y.; Hong, S.M.; Aoyama, K.; Fan, Y.; Kayama, T.; Sheldon, R.A.; Vexler, Z.S.; Ferriero, D.M.; Weinstein, P.R.; Liu, J. Hsp70 overexpression sequesters aif and reduces neonatal hypoxic/ischemic brain injury. J. Cereb. Blood Flow Metab. 2005, 25, 899-910. [CrossRef] [PubMed]

62. Beere, H.M.; Wolf, B.B.; Cain, K.; Mosser, D.D.; Mahboubi, A.; Kuwana, T.; Tailor, P.; Morimoto, R.I.; Cohen, G.M.; Green, D.R. Heat-shock protein 70 inhibits apoptosis by preventing recruitment of procaspase-9 to the apaf-1 apoptosome. Nat. Cell Biol. 2000, 2, 469-475. [CrossRef] [PubMed]

63. Jiang, B.; Xiao, W.; Shi, Y.; Liu, M.; Xiao, X. Heat shock pretreatment inhibited the release of smac/diablo from mitochondria and apoptosis induced by hydrogen peroxide in cardiomyocytes and c2c12 myogenic cells. Cell Stress. Chaperones 2005, 10, 252-262. [CrossRef]

64. Geissler, A.; Krimmer, T.; Bomer, U.; Guiard, B.; Rassow, J.; Pfanner, N. Membrane potential-driven protein import into mitochondria. The sorting sequence of cytochrome $b(2)$ modulates the deltapsi-dependence of translocation of the matrix-targeting sequence. Mol. Biol. Cell 2000, 11, 3977-3991. [CrossRef] [PubMed]

65. Voloboueva, L.A.; Duan, M.; Ouyang, Y.; Emery, J.F.; Stoy, C.; Giffard, R.G. Overexpression of mitochondrial hsp70/hsp75 protects astrocytes against ischemic injury in vitro. J. Cereb. Blood Flow Metab. 2008, 28, 1009-1016. [CrossRef]

66. Ouyang, Y.B.; Xu, L.J.; Sun, Y.J.; Giffard, R.G. Overexpression of inducible heat shock protein 70 and its mutants in astrocytes is associated with maintenance of mitochondrial physiology during glucose deprivation stress. Cell Stress Chaperones 2006, 11, 180-186. [CrossRef]

67. Xu, L.; Giffard, R.G. Hsp70 protects murine astrocytes from glucose deprivation injury. Neurosci. Lett. 1997, 224, 9-12. [CrossRef]

68. Suzuki, K.; Murtuza, B.; Sammut, I.A.; Latif, N.; Jayakumar, J.; Smolenski, R.T.; Kaneda, Y.; Sawa, Y.; Matsuda, H.; Yacoub, M.H. Heat shock protein 72 enhances manganese superoxide dismutase activity during myocardial ischemia-reperfusion injury, associated with mitochondrial protection and apoptosis reduction. Circulation 2002, 106, I270-I276.

69. Kelly, S.; Yenari, M.A. Neuroprotection: Heat shock proteins. Curr. Med. Res. Opin. 2002, 18 (Suppl. 2), s55-s60. [CrossRef]

70. Havasi, A.; Li, Z.; Wang, Z.; Martin, J.L.; Botla, V.; Ruchalski, K.; Schwartz, J.H.; Borkan, S.C. Hsp27 inhibits bax activation and apoptosis via a phosphatidylinositol 3-kinase-dependent mechanism. J. Biol. Chem. 2008, 283, 12305-12313. [CrossRef]

71. Rane, M.J.; Pan, Y.; Singh, S.; Powell, D.W.; Wu, R.; Cummins, T.; Chen, Q.; McLeish, K.R.; Klein, J.B. Heat shock protein 27 controls apoptosis by regulating akt activation. J. Biol. Chem. 2003, 278, 27828-27835. [CrossRef] [PubMed]

72. Schepers, H.; Geugien, M.; van der Toorn, M.; Bryantsev, A.L.; Kampinga, H.H.; Eggen, B.J.; Vellenga, E. Hsp27 protects aml cells against vp-16-induced apoptosis through modulation of p38 and c-jun. Exp. Hematol. 2005, 33, 660-670. [CrossRef] [PubMed]

73. Namura, S.; Zhu, J.; Fink, K.; Endres, M.; Srinivasan, A.; Tomaselli, K.J.; Yuan, J.; Moskowitz, M.A. Activation and cleavage of caspase-3 in apoptosis induced by experimental cerebral ischemia. J. Neurosci. 1998, 18, 3659-3668. [CrossRef] [PubMed]

74. del Zoppo, G.J.; Mabuchi, T. Cerebral microvessel responses to focal ischemia. J. Cereb. Blood Flow Metab. 2003, 23, 879-894. [CrossRef]

75. Love, S. Apoptosis and brain ischaemia. Prog. Neuropsychopharmacol. Biol. Psychiatry 2003, 27, $267-282$. [CrossRef]

76. Jin, K.; Graham, S.H.; Mao, X.; Nagayama, T.; Simon, R.P.; Greenberg, D.A. Fas (cd95) may mediate delayed cell death in hippocampal ca1 sector after global cerebral ischemia. J. Cereb. Blood Flow Metab. 2001, 21, 1411-1421. [CrossRef]

77. Guo, F.; Sigua, C.; Bali, P.; George, P.; Fiskus, W.; Scuto, A.; Annavarapu, S.; Mouttaki, A.; Sondarva, G.; Wei, S.; et al. Mechanistic role of heat shock protein 70 in bcr-abl-mediated resistance to apoptosis in human acute leukemia cells. Blood 2005, 105, 1246-1255. [CrossRef]

78. Schulze-Osthoff, K.; Ferrari, D.; Los, M.; Wesselborg, S.; Peter, M.E. Apoptosis signaling by death receptors. Eur. J. Biochem. 1998, 254, 439-459. [CrossRef]

79. Gabai, V.L.; Mabuchi, K.; Mosser, D.D.; Sherman, M.Y. Hsp72 and stress kinase c-jun n-terminal kinase regulate the bid-dependent pathway in tumor necrosis factor-induced apoptosis. Mol. Cell. Biol. 2002, 22, 3415-3424. [CrossRef] 
80. Ivanov, V.N.; Ronai, Z.; Hei, T.K. Opposite roles of fap-1 and dynamin in the regulation of fas (cd95) translocation to the cell surface and susceptibility to fas ligand-mediated apoptosis. J. Biol. Chem. 2006, 281, 1840-1852. [CrossRef]

81. Shan, Z.X.; Lin, Q.X.; Fu, Y.H.; Deng, C.Y.; Zhou, Z.L.; Zhu, J.N.; Liu, X.Y.; Zhang, Y.Y.; Li, Y.; Lin, S.G.; et al. Upregulated expression of mir-1/mir-206 in a rat model of myocardial infarction. Biochem. Biophys. Res. Commun. 2009, 381, 597-601. [CrossRef] [PubMed]

82. Tang, Y.; Zheng, J.; Sun, Y.; Wu, Z.; Liu, Z.; Huang, G. Microrna-1 regulates cardiomyocyte apoptosis by targeting bcl-2. Int. Heart J. 2009, 50, 377-387. [CrossRef] [PubMed]

83. Yang, B.; Lin, H.; Xiao, J.; Lu, Y.; Luo, X.; Li, B.; Zhang, Y.; Xu, C.; Bai, Y.; Wang, H.; et al. The muscle-specific microrna mir-1 regulates cardiac arrhythmogenic potential by targeting gja1 and kcnj2. Nat. Med. 2007, 13, 486-491. [CrossRef] [PubMed]

84. Xu, C.; Lu, Y.; Pan, Z.; Chu, W.; Luo, X.; Lin, H.; Xiao, J.; Shan, H.; Wang, Z.; Yang, B. The muscle-specific micrornas mir-1 and mir-133 produce opposing effects on apoptosis by targeting hsp60, hsp70 and caspase-9 in cardiomyocytes. J. Cell Sci. 2007, 120, 3045-3052. [CrossRef]

85. Ouyang, Y.B.; Lu, Y.; Yue, S.; Xu, L.J.; Xiong, X.X.; White, R.E.; Sun, X.; Giffard, R.G. Mir-181 regulates grp78 and influences outcome from cerebral ischemia in vitro and in vivo. Neurobiol. Dis. 2012, 45, 555-563. [CrossRef]

86. Ouyang, Y.B.; Lu, Y.; Yue, S.; Giffard, R.G. Mir-181 targets multiple bcl-2 family members and influences apoptosis and mitochondrial function in astrocytes. Mitochondrion 2012, 12, 213-219. [CrossRef]

87. Wang, J.; Dore, S. Heme oxygenase-1 exacerbates early brain injury after intracerebral haemorrhage. Brain 2007, 130, 1643-1652. [CrossRef]

88. Davies, C.A.; Loddick, S.A.; Stroemer, R.P.; Hunt, J.; Rothwell, N.J. An integrated analysis of the progression of cell responses induced by permanent focal middle cerebral artery occlusion in the rat. Exp. Neurol. 1998, 154, 199-212. [CrossRef]

89. Zheng, Z.; Yenari, M.A. Post-ischemic inflammation: Molecular mechanisms and therapeutic implications. Neurol. Res. 2004, 26, 884-892. [CrossRef]

90. Mehta, S.L.; Manhas, N.; Raghubir, R. Molecular targets in cerebral ischemia for developing novel therapeutics. Brain Res. Rev. 2007, 54, 34-66. [CrossRef]

91. Feinstein, D.L.; Galea, E.; Aquino, D.A.; Li, G.C.; Xu, H.; Reis, D.J. Heat shock protein 70 suppresses astroglial-inducible nitric-oxide synthase expression by decreasing nfkappab activation. J. Biol. Chem. 1996, 271, 17724-17732. [CrossRef] [PubMed]

92. Gu, S.X.; Blokhin, I.O.; Wilson, K.M.; Dhanesha, N.; Doddpattar, P.; Grumbach, I.M.; Chauhan, A.K.; Lentz, S.R. Protein methionine oxidation augments reperfusion injury in acute ischemic stroke. JCI Insight 2016, 1, e86460. [CrossRef] [PubMed]

93. Van Molle, W.; Wielockx, B.; Mahieu, T.; Takada, M.; Taniguchi, T.; Sekikawa, K.; Libert, C. Hsp70 protects against tnf-induced lethal inflammatory shock. Immunity 2002, 16, 685-695. [CrossRef]

94. Ding, X.Z.; Fernandez-Prada, C.M.; Bhattacharjee, A.K.; Hoover, D.L. Over-expression of hsp-70 inhibits bacterial lipopolysaccharide-induced production of cytokines in human monocyte-derived macrophages. Cytokine 2001, 16, 210-219. [CrossRef] [PubMed]

95. Manaenko, A.; Fathali, N.; Chen, H.; Suzuki, H.; Williams, S.; Zhang, J.H.; Tang, J. Heat shock protein 70 upregulation by geldanamycin reduces brain injury in a mouse model of intracerebral hemorrhage. Neurochem. Int. 2010, 57, 844-850. [CrossRef] [PubMed]

96. Polla, B.S.; Stubbe, H.; Kantengwa, S.; Maridonneau-Parini, I.; Jacquier-Sarlin, M.R. Differential induction of stress proteins and functional effects of heat shock in human phagocytes. Inflammation 1995, 19, 363-378. [CrossRef]

97. Kim, J.Y.; Yenari, M.A.; Lee, J.E. Regulation of inflammatory transcription factors by heat shock protein 70 in primary cultured astrocytes exposed to oxygen-glucose deprivation. Neuroscience 2015, 286, $272-280$. [CrossRef]

98. Guzhova, I.V.; Darieva, Z.A.; Melo, A.R.; Margulis, B.A. Major stress protein hsp70 interacts with nf-kb regulatory complex in human t-lymphoma cells. Cell Stress Chaperones 1997, 2, 132-139. [CrossRef]

99. Heneka, M.T.; Sharp, A.; Klockgether, T.; Gavrilyuk, V.; Feinstein, D.L. The heat shock response inhibits nf-kappab activation, nitric oxide synthase type 2 expression, and macrophage/microglial activation in brain. J. Cereb. Blood Flow Metab. 2000, 20, 800-811. [CrossRef] 
100. Zheng, Z.; Kim, J.Y.; Ma, H.; Lee, J.E.; Yenari, M.A. Anti-inflammatory effects of the 70 kda heat shock protein in experimental stroke. J. Cereb. Blood Flow Metab. 2008, 28, 53-63. [CrossRef]

101. Ran, R.; Zhou, G.; Lu, A.; Zhang, L.; Tang, Y.; Rigby, A.C.; Sharp, F.R. Hsp70 mutant proteins modulate additional apoptotic pathways and improve cell survival. Cell Stress Chaperones 2004, 9, 229-242. [CrossRef] [PubMed]

102. Ran, R.; Lu, A.; Zhang, L.; Tang, Y.; Zhu, H.; Xu, H.; Feng, Y.; Han, C.; Zhou, G.; Rigby, A.C.; et al. Hsp70 promotes tnf-mediated apoptosis by binding ikk gamma and impairing nf-kappa b survival signaling. Genes Dev. 2004, 18, 1466-1481. [CrossRef] [PubMed]

103. Johnston, J.B.; Jiang, Y.; van Marle, G.; Mayne, M.B.; Ni, W.; Holden, J.; McArthur, J.C.; Power, C. Lentivirus infection in the brain induces matrix metalloproteinase expression: Role of envelope diversity. J. Virol. 2000, 74, 7211-7220. [CrossRef] [PubMed]

104. Giffard, R.G.; Han, R.Q.; Emery, J.F.; Duan, M.; Pittet, J.F. Regulation of apoptotic and inflammatory cell signaling in cerebral ischemia: The complex roles of heat shock protein 70. Anesthesiology 2008, 109, 339-348. [CrossRef] [PubMed]

105. Singh-Jasuja, H.; Toes, R.E.; Spee, P.; Munz, C.; Hilf, N.; Schoenberger, S.P.; Ricciardi-Castagnoli, P.; Neefjes, J.; Rammensee, H.G.; Arnold-Schild, D.; et al. Cross-presentation of glycoprotein 96-associated antigens on major histocompatibility complex class i molecules requires receptor-mediated endocytosis. J. Exp. Med. 2000, 191, 1965-1974. [CrossRef] [PubMed]

106. Haug, M.; Dannecker, L.; Schepp, C.P.; Kwok, W.W.; Wernet, D.; Buckner, J.H.; Kalbacher, H.; Dannecker, G.E.; Holzer, U. The heat shock protein hsp70 enhances antigen-specific proliferation of human cd4+ memory t cells. Eur. J. Immunol. 2005, 35, 3163-3172. [CrossRef]

107. de Jong, P.R.; Schadenberg, A.W.; Jansen, N.J.; Prakken, B.J. Hsp70 and cardiac surgery: Molecular chaperone and inflammatory regulator with compartmentalized effects. Cell Stress Chaperones 2009, 14, 117-131. [CrossRef]

108. Srivastava, P. Roles of heat-shock proteins in innate and adaptive immunity. Nat. Rev. Immunol. 2002, 2, 185-194. [CrossRef]

109. Asea, A. Heat shock proteins and toll-like receptors. Handb. Exp. Pharmacol. 2008, 111-127. [CrossRef]

110. Gaston, J.S. Heat shock proteins and innate immunity. Clin. Exp. Immunol. 2002, 127, 1-3. [CrossRef]

111. Doeppner, T.R.; Nagel, F.; Dietz, G.P.; Weise, J.; Tonges, L.; Schwarting, S.; Bahr, M. Tat-hsp70-mediated neuroprotection and increased survival of neuronal precursor cells after focal cerebral ischemia in mice. J. Cereb. Blood Flow Metab. 2009, 29, 1187-1196. [CrossRef] [PubMed]

112. Zhan, X.; Ander, B.P.; Liao, I.H.; Hansen, J.E.; Kim, C.; Clements, D.; Weisbart, R.H.; Nishimura, R.N.; Sharp, F.R. Recombinant fv-hsp70 protein mediates neuroprotection after focal cerebral ischemia in rats. Stroke 2010, 41, 538-543. [CrossRef] [PubMed]

113. Lu, A.; Ran, R.; Parmentier-Batteur, S.; Nee, A.; Sharp, F.R. Geldanamycin induces heat shock proteins in brain and protects against focal cerebral ischemia. J. Neurochem. 2002, 81, 355-364. [CrossRef] [PubMed]

114. Li, J.; Yang, F.; Guo, J.; Zhang, R.; Xing, X.; Qin, X. 17-aag post-treatment ameliorates memory impairment and hippocampal ca1 neuronal autophagic death induced by transient global cerebral ischemia. Brain Res. 2015, 1610, 80-88. [CrossRef] [PubMed]

115. Peng, R.; Li, Z.; Lin, Z.; Wang, Y.; Wang, W.; Hu, B.; Wang, X.; Zhang, J.; Wang, Y.; Zhou, R.; et al. The hsp90 inhibitor 17-pag effectively inhibits the proliferation and migration of androgen-independent prostate cancer cells. Am. J. Cancer Res. 2015, 5, 3198-3209.

116. Supko, J.G.; Hickman, R.L.; Grever, M.R.; Malspeis, L. Preclinical pharmacologic evaluation of geldanamycin as an antitumor agent. Cancer Chemother. Pharmacol. 1995, 36, 305-315. [CrossRef]

117. Neckers, L.; Workman, P. Hsp90 molecular chaperone inhibitors: Are we there yet? Clin. Cancer Res. 2012, 18, 64-76. [CrossRef]

118. Porter, J.R.; Fritz, C.C.; Depew, K.M. Discovery and development of hsp90 inhibitors: A promising pathway for cancer therapy. Curr. Opin. Chem Biol. 2010, 14, 412-420. [CrossRef]

119. Kim, N.; Kim, J.Y.; Yenari, M.A. Pharmacological induction of the 70-kda heat shock protein protects against brain injury. Neuroscience 2015, 284, 912-919. [CrossRef]

120. Qi, J.; Han, X.; Liu, H.T.; Chen, T.; Zhang, J.L.; Yang, P.; Bo, S.H.; Lu, X.T.; Zhang, J. 17-dimethylaminoethylamino-17-demethoxygeldanamycin attenuates inflammatory responses in experimental stroke. Biol. Pharm. Bull 2014, 37, 1713-1718. [CrossRef] 
121. Jones, Q.; Voegeli, T.S.; Li, G.; Chen, Y.; Currie, R.W. Heat shock proteins protect against ischemia and inflammation through multiple mechanisms. Inflamm. Allergy Drug Targets 2011, 10, 247-259. [CrossRef] [PubMed]

122. Lundgren, K.; Zhang, H.; Brekken, J.; Huser, N.; Powell, R.E.; Timple, N.; Busch, D.J.; Neely, L.; Sensintaffar, J.L.; Yang, Y.C.; et al. Biib021, an orally available, fully synthetic small-molecule inhibitor of the heat shock protein hsp90. Mol. Cancer Ther. 2009, 8, 921-929. [CrossRef] [PubMed]

123. Boll, B.; Eltaib, F.; Reiners, K.S.; von Tresckow, B.; Tawadros, S.; Simhadri, V.R.; Burrows, F.J.; Lundgren, K.; Hansen, H.P.; Engert, A.; et al. Heat shock protein 90 inhibitor biib021 (cnf2024) depletes nf-kappab and sensitizes hodgkin's lymphoma cells for natural killer cell-mediated cytotoxicity. Clin. Cancer Res. 2009, 15, 5108-5116. [CrossRef] [PubMed]

124. Roe, S.M.; Prodromou, C.; O’Brien, R.; Ladbury, J.E.; Piper, P.W.; Pearl, L.H. Structural basis for inhibition of the hsp90 molecular chaperone by the antitumor antibiotics radicicol and geldanamycin. J. Med. Chem. 1999, 42, 260-266. [CrossRef] [PubMed]

125. Brough, P.A.; Aherne, W.; Barril, X.; Borgognoni, J.; Boxall, K.; Cansfield, J.E.; Cheung, K.M.; Collins, I.; Davies, N.G.; Drysdale, M.J.; et al. 4,5-diarylisoxazole hsp90 chaperone inhibitors: Potential therapeutic agents for the treatment of cancer. J. Med. Chem. 2008, 51, 196-218. [CrossRef] [PubMed]

126. Yasuda, H.; Shichinohe, H.; Kuroda, S.; Ishikawa, T.; Iwasaki, Y. Neuroprotective effect of a heat shock protein inducer, geranylgeranylacetone in permanent focal cerebral ischemia. Brain Res. 2005, 1032, $176-182$. [CrossRef]

127. Uchida, S.; Fujiki, M.; Nagai, Y.; Abe, T.; Kobayashi, H. Geranylgeranylacetone, a noninvasive heat shock protein inducer, induces protein kinase $\mathrm{c}$ and leads to neuroprotection against cerebral infarction in rats. Neurosci. Lett. 2006, 396, 220-224. [CrossRef]

128. Zhao, Z.; Faden, A.I.; Loane, D.J.; Lipinski, M.M.; Sabirzhanov, B.; Stoica, B.A. Neuroprotective effects of geranylgeranylacetone in experimental traumatic brain injury. J. Cereb. Blood Flow Metab. 2013, 33, 1897-1908. [CrossRef]

129. Joshi, V.; Mishra, R.; Upadhyay, A.; Amanullah, A.; Poluri, K.M.; Singh, S.; Kumar, A.; Mishra, A. Polyphenolic flavonoid (myricetin) upregulated proteasomal degradation mechanisms: Eliminates neurodegenerative proteins aggregation. J. Cell Physiol. 2019, 234, 20900-20914. [CrossRef]

130. Deane, C.A.; Brown, I.R. Induction of heat shock proteins in differentiated human neuronal cells following co-application of celastrol and arimoclomol. Cell Stress Chaperones 2016, 21, 837-848. [CrossRef]

131. Petrovic, A.; Kaur, J.; Tomljanovic, I.; Nistri, A.; Mladinic, M. Pharmacological induction of heat shock protein 70 by celastrol protects motoneurons from excitotoxicity in rat spinal cord in vitro. Eur. J. Neurosci. 2019, 49, 215-231. [CrossRef] [PubMed]

132. Jiang, M.; Liu, X.; Zhang, D.; Wang, Y.; Hu, X.; Xu, F.; Jin, M.; Cao, F.; Xu, L. Celastrol treatment protects against acute ischemic stroke-induced brain injury by promoting an il-33/st2 axis-mediated microglia/macrophage m2 polarization. J. Neuroinflamm. 2018, 15, 78. [CrossRef] [PubMed]

133. Maczynska, J.; Choromanska, A.; Kutkowska, J.; Kotulska, M.; Zalewski, M.; Zalewski, J.; Kulbacka, J.; Saczko, J. Effect of electrochemotherapy with betulinic acid or cisplatin on regulation of heat shock proteins in metastatic human carcinoma cells in vitro. Oncol. Rep. 2019, 41, 3444-3454. [CrossRef] [PubMed]

(C) 2020 by the authors. Licensee MDPI, Basel, Switzerland. This article is an open access article distributed under the terms and conditions of the Creative Commons Attribution (CC BY) license (http://creativecommons.org/licenses/by/4.0/). 